\title{
Molecular basis of transfusion dependent beta-thalassemia major patients in Sabah
}

\author{
Lai Kuan Teh ${ }^{1}$, Elizabeth George ${ }^{1}$, Mei I Lai ${ }^{1}$, Jin Ai Mary Anne Tan $^{2}$, Lily Wong ${ }^{3}$ and Patimah Ismail ${ }^{4}$ \\ Beta-thalassemia is one of the most prevalent inherited diseases and a public health problem in Malaysia. Malaysia is \\ geographically divided into West and East Malaysia. In Sabah, a state in East Malaysia, there are over 1000 estimated cases \\ of $\beta$-thalassemia major patients. Accurate population frequency data of the molecular basis of $\beta$-thalassemia major are needed \\ for planning its control in the high-risk population of Sabah. Characterization of $\beta$-globin gene defects was done in 252 \\ transfusion dependent $\beta$-thalassemia patients incorporating few PCR techniques. The study demonstrates that $\beta$-thalassemia \\ mutations inherited are ethnically dependent. It is important to note that $86.9 \%$ of transfusion-dependent $\beta$-thalassemia major \\ patients in Sabah were of the indigenous population and homozygous for a single mutation. The Filipino $\beta^{0}$-deletion was a \\ unique mutation found in the indigenous population of Sabah. Mutations common in West Malaysia were found in 11 (4.3\%) \\ patients. Four rare mutations (Hb Monroe, CD 8/9, CD 123/124/125 and IVS I-2) were also found. This study is informative on \\ the population genetics of $\boldsymbol{\beta}$-thalassemia major in Sabah.
}

Journal of Human Genetics (2014) 59, 119-123; doi:10.1038/jhg.2013.131; published online 26 December 2013

Keywords: $\beta$ globin gene mutations; beta thalassemia; filipino $\beta^{0}$-deletion; indigenous population; Sabah

\section{INTRODUCTION}

Geographically, Malaysia is divided into West Malaysia (Peninsular Malaysia) and East Malaysia. The population is over 28.3 million and multiethnic, ${ }^{1}$ where $\sim 80 \%$ are from West Malaysia and $20 \%$ are from East Malaysia (Sabah and Sarawak). ${ }^{2}$ In East Malaysia, the population of Sabah and Sarawak are 70 and 50\% indigenous, respectively. The population in Sabah was 3117405 in the year 2013, ${ }^{3}$ and divided into 35 officially recognized ethnic groups. ${ }^{4}$ The racial groups are heterogeneous where the largest indigenous ethnic group in Sabah is the Kadazandusun (25\%), followed by Bajau (15\%) and Murut $(3 \%){ }^{3}$

Beta-thalassemia major $(\beta-\mathrm{TM})$ is the most common inherited disorder of hemoglobin synthesis and a recognized public health problem in Malaysia. ${ }^{5,6}$ The total number of transfusion-dependent thalassemia patients was 4768 in May 2010 (National Thalassaemia Registry), where the estimated transfusion dependent $\beta$-TM in Sabah was over 1000 cases.

$\beta$-thalassemia is characterized by a quantitative deficiency of functional $\beta$-globin chains, leading to an imbalanced globin chain production and an excess of $\alpha$-globin chains. Precipitation of excess $\alpha$-globin chains results in damage of the red cell precursor membrane leading to apoptosis and extensive intramedullary destruction of erythroid precursors in the bone marrow (ineffective erythropoiesis). ${ }^{7,8}$ Wide spectrum of disease severity is a consequence of affected genes by different allele/mutations or different combinations of mutations inherited. ${ }^{9} \beta$-thalasssaemia allele is the most consistent genotypic factor in prediction of phenotype of thalassemia. ${ }^{10}$ There are over 200 mutations reported that affect transcription, translation or RNA processing. Carriers or heterozygous for $\beta$-globin gene mutations are clinically normal and go through their life unaware of their carrier status. However, they have a $25 \%$ risk of having a child with $\beta$-TM in each pregnancy when both partners are $\beta$-thalassemia carriers. $\beta$-TM patient is transfusion dependent and requires iron chelation for life. ${ }^{11,12}$ Mortality and morbidity in $\beta$-TM patients can be caused by the complications of iron overload, including sequelae of anemia, ineffective erythropoiesis and chelation therapy. ${ }^{12,13}$

Each ethnic group has a common set of four to five mutations that comprises more than $95 \%$ of the mutations seen. ${ }^{11}$ In the last 15 years, the $\beta$-globin mutations has been well documented in the main racial groups in Peninsular Malaysia (West Malaysia) (Malays and Chines $\left.\mathrm{e}^{5,6,14-20}\right)$. The common $\beta$-globin mutations that account for $73 \%$ of the mutations in Malays are Hb E, IVS I-5 $(\mathrm{G} \rightarrow \mathrm{C})$ and IVS $\mathrm{I}-1(\mathrm{G} \rightarrow \mathrm{T})$. The common $\beta$-globin mutations that account for $90 \%$ of the mutations in Chinese-Malaysians are CD 41/42 (-TCTT), IVS II-654 $(\mathrm{C} \rightarrow \mathrm{T}),-28(\mathrm{~A} \rightarrow \mathrm{G}), \mathrm{CD} 17(\mathrm{~A} \rightarrow \mathrm{T})$ and $\mathrm{CD}$ 71/72 $(+\mathrm{A})$, respectively. ${ }^{5,6,14-20}$ The complete spectrum of $\beta$-thalassemia mutations in East Malaysia is still unknown. Multiethnic migration from Brunei, Philippines and other places to this region makes the

${ }^{1}$ Department of Pathology, Faculty of Medicine and Health Sciences, Universiti Putra Malaysia, Serdang, Malaysia; ${ }^{2}$ Department of Biomedical Science, Faculty of Medicine, University of Malaya, Kuala Lumpur, Malaysia; ${ }^{3}$ Department of Medicine, Hospital Queen Elizabeth, Kota Kinabalu, Malaysia and ${ }^{4}$ Department of Biomedical Sciences, Faculty of Medicine and Health Sciences, Universiti Putra Malaysia, Serdang, Malaysia

Correspondence: Dr E George, Department of Pathology, Faculty of Medicine and Health Sciences, Universiti Putra Malaysia, 43400 Serdang, Selangor, Malaysia. E-mail: eliza@upm.edu.my

Received 15 July 2013; revised 28 November 2013; accepted 29 November 2013; published online 26 December 2013 
identification of $\beta$-thalassemia more complex. However, previous studies in limited number of $\beta$-TM patients from Sabah indicated the large $\beta$-globin gene deletion (Filipino $\beta^{\circ}$-deletion) is the most common mutation found. ${ }^{20-22}$

In this report, mutations in transfusion dependent $\beta$-TM patients from Sabah population were delineated using molecular analysis. As Filipino $\beta^{0}$-deletion was a common mutation noted in previous studies, the patient's DNA was first analyzed by Gap-PCR, followed by reverse dot blot hybridization and amplification refractory mutation system for mutations frequently encountered in West Malaysia. DNA sequencing was done to identify unknown mutations. In developing countries including Malaysia, technology for molecular analysis of thalassemia is limited. Elucidation of the spectrum of mutations that are largely ethnic-specific in their distribution will be informative for development of cost-effective and feasible PCR-based methods to identify $\beta$-thalassemia in this region.

\section{MATERIALS AND METHODS}

\section{Study subjects}

In this study, a total of 252 blood samples were collected from transfusiondependent $\beta$-TM patients from 11 hospitals in different regions of Sabah. Approval was obtained from Medical Ethics Committee of the Faculty of Medicine and Health Sciences, Universiti Putra Malaysia (UPM/FPSK/PADS/ T7-MJKEtikaPer/F01(JPAT_JUL(10)06)) and the Ministry of Health Medical Research Ethics Committee (NMRR-10-850-7075). The study was conducted in concordance with the declaration of Helsinki. Written informed consent was obtained from the study participants before blood sample collection.

\section{DNA isolation}

Two milliliters of venous blood was collected in ethylenediamine tetraacetic acid (EDTA) vacutainers from $\beta$-TM patients. Genomic DNA was extracted from leukocytes in peripheral whole blood samples by using QIAamp DNA midi kit (Qiagen GmbH, Hilden, Germany). Quality and quantity of the extracted genomic DNA were determined using Nanodrop 1000 Spectrophotometer (Thermo Scientific, Thermo Fisher Scientific Inc., Wilmington, DE, USA) and gel electrophoresis using $0.8 \%$ ethidium bromide-stained agarose gel in $1 \times$ tris-acetic-EDTA buffer at $10 \mathrm{~V} \mathrm{~cm}^{-1}$ for $20 \mathrm{~min}$.

\section{Beta globin gene analysis}

Filipino $\beta^{0}$-deletion: Gap-PCR. Gap-PCR technique was performed by using specific primers that flank across the deleted region of the $\beta$-globin gene complex according to previous published assay. ${ }^{23}$ PCR amplification was conducted in $25 \mu \mathrm{l}$ reaction volume containing $100 \mathrm{ng}$ genomic DNA, a mixture of $2.5 \mathrm{mM} \mathrm{MgCl}_{2}, 0.4 \mu \mathrm{M}$ of the two forward primers, $0.6 \mu \mathrm{M}$ of reverse primer, $50 \mathrm{~mm} \mathrm{KCl,} 10 \mathrm{~mm}$ Tris $(\mathrm{pH} 8.3), 200 \mu \mathrm{M}$ of mixture dNTP, $0.02 \mathrm{U}_{\mu \mathrm{l}^{-1}}$ Taq polymerase and $2 \%$ glycerol. The cycling reaction was performed in a programmable thermal cycler (Takara PCR thermal cycler Dice, TP600 gradient, Takara Bio Inc., Otsu, Shiga, Japan) at initial denaturation for $5 \mathrm{~min}$ at $95^{\circ} \mathrm{C}$, followed by 35 cycles of $95^{\circ} \mathrm{C}$ denaturation for $1 \mathrm{~min}, 60^{\circ} \mathrm{C}$ annealing for $1 \mathrm{~min}, 72^{\circ} \mathrm{C}$ extension for $1 \mathrm{~min}$ and a final extension for $10 \mathrm{~min}$ at $72^{\circ} \mathrm{C}$. Each amplified product $(10 \mu \mathrm{l})$ was analyzed using $1.5 \%$ ethidium bromide-stained agarose gel in $1 \mathrm{X}$ TAE buffer at 10 volts $\mathrm{cm}^{-1}$ for an hour. The gel was then visualized on an ultraviolet transilluminator (G:box bioimaging systems, Synoptics Ltd, Cambridge, UK). If Gap-PCR failed to detect the mutation, the samples were further analyzed for point mutations.

Point mutations detection: reverse dot blot hybridization-strip assay. A total of 33 samples consisting of $22 \beta$-TM heterozygous for the Filipino $\beta^{0}$-deletion and 11 with unidentified mutations were further analyzed for another $22 \beta$ thalassemia mutations using $\beta$-globin strip assay (Viennalab Diagnostics $\mathrm{GmbH}$, Vienna, Austria). The $22 \beta$-globin mutations screened for were: -31 $(\mathrm{A} \rightarrow \mathrm{G})$ [NM_000518.4:c.-50-31A $>\mathrm{G}$ ]; $\quad-29(\mathrm{~A} \rightarrow \mathrm{G})$ [NM_000518.4:c.-50$29 \mathrm{~A}>\mathrm{G}] ; \quad-28 \quad(\mathrm{~A} \rightarrow \mathrm{G}) \quad$ [NM_000518.4:c.-50-28A $>$ G]; $\quad \mathrm{CAP}+1 \quad(\mathrm{~A} \rightarrow \mathrm{C})$
[NM_000518.4:c.-50A $>C$ ]; Init CD ATG > AGG [NM_000518.4:c.2T $>$ G]; $\mathrm{CD} \quad 8 / 9 \quad(+\mathrm{G}) \quad$ [NM_000518.4:c.27_28insG], $\quad \mathrm{CD} \quad 15 \quad$ (TGG $\rightarrow$ TAG) [NM_000518.4:c.47G > A]; CD $17(\mathrm{~A} \rightarrow \mathrm{T})$ [NM_000518.4:c.52A > T];CD 19 $(\mathrm{AAC} \rightarrow$ AGC; Asn $\rightarrow$ Ser; Hb Malay) [NM_000518.4:c.59A $>$ G]; CD $26(\mathrm{G} \rightarrow$ A; Glu $\rightarrow$ Lys; $\quad \mathrm{Hb} \quad$ E) [NM_000518.4:c.79G $>$ A]; CD 27/28 (+C) [NM_000518.4:c.84_85insC]; IVS I-I $(\mathrm{G} \rightarrow \mathrm{T})$ [NM_000518.4:c.92 + $1 \mathrm{G}>\mathrm{T}$ ]; IVS I-5 $(\mathrm{G} \rightarrow \mathrm{C}) \quad$ [NM_000518.4:c.92 + 5G $>$ C]; CD $\quad 41 / 42$ (-TTCT) [NM_000518.4:c.124_127delTTCT]; CD $43 \quad$ (GAG $\rightarrow$ TAG) [NM_000518.4:c.130G > T]; CD 71/72 (+ A) [NM_000518.4:c.216_217insA]; CD 89/9 (-GT)[NM_000518.4:c.269_270delGT]; CD $90 \quad$ (GAG $\rightarrow$ TAG) [NM_000518.4:c.271G > T]; CD 95 (+A) [NM_000518.4:c.287_288insA];

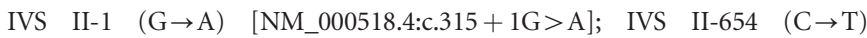
$\left[\mathrm{NM} \_000518.4: c .316-197 \mathrm{C}>\mathrm{T}\right]$ and CD $121(\mathrm{GAA} \rightarrow \mathrm{TAA} ; \mathrm{Glu} \rightarrow$ TermCD $)$ [NM_000518.4:c.364G > T].

Point mutations detection: amplification refractory mutation system-PCR. amplification refractory mutation system-PCR was run in parallel for the detection of the 12 common $\beta$-thalassemia mutations seen in Malaysia ${ }^{24,25}$ $(\mathrm{Hb}$ E, Hb Malay, IVS I-5 $(\mathrm{G} \rightarrow \mathrm{C})$, IVS I-1 $(\mathrm{G} \rightarrow \mathrm{T}), \mathrm{CD} 8 / 9(+\mathrm{G}), \mathrm{CAP}+1$ $(\mathrm{A} \rightarrow \mathrm{C}), \mathrm{CD}$ 41/42 (-TTCT), IVS II-654 $(\mathrm{C} \rightarrow \mathrm{T}), \mathrm{CD} 17(\mathrm{~A} \rightarrow \mathrm{T}),-28(\mathrm{~A} \rightarrow \mathrm{G})$, $-29(\mathrm{~A} \rightarrow \mathrm{G})$ and $\mathrm{CD} 71 / 72(+\mathrm{A}))$.

When the reverse dot blot hybridization and amplification refractory mutation system-PCR assays were unable to detect any mutations, sequencing of $\beta$-globin gene was performed.

Unknown mutations detection: DNA Sequencing. The $1.6 \mathrm{~kb}$ of $\beta$-globin gene including the $5^{\prime}$ and $3^{\prime}$ untranslated region was amplified in three fragments. $5^{\prime}$ promoter region, $5^{\prime}$ untranslated region, exon 1 , intron 1 and part of exon 2 were amplified using primer $\beta$ A-Fw (5'-CGATCTTCAATATGCTTACCAA- $\left.3^{\prime}\right)$ and $\beta \mathrm{A}-\mathrm{Rv}$ (5'-AACGATCCTGAGACTTCCACA-3') as a $947 \mathrm{bp}$ fragment. Intron 2 was amplified using primer $\beta \mathrm{B}$-Fw (5'-GCACGTGGATCCTGAGAACT- $3^{\prime}$ ) and $\beta \mathrm{B}-\mathrm{Rv}$ (5'-CACACAGACCAGCACGTTG-3') as a $901 \mathrm{bp}$ fragment. Exon 3 and $3^{\prime}$ untranslated region were amplified using primer $\beta C$-Fw (5'-GCTAATCATGTTCATACCTCTT-3') and $\beta C$-Rv (5'-CAGATTCC GGGTCACTGTG- $3^{\prime}$ ) as a $854 \mathrm{bp}$ fragment. ${ }^{26,27}$ PCR amplification was conducted in $50 \mu \mathrm{l}$ reaction volume containing $100 \mathrm{ng}$ genomic DNA, $2.5 \mathrm{mM} \mathrm{MgCl}_{2}, 0.4 \mu \mathrm{mol}$ of each primer, $50 \mathrm{~mm} \mathrm{KCl}, 10 \mathrm{~mm}$ tris $(\mathrm{pH} 8.3$ ), $200 \mu \mathrm{m}$ of each dNTP and $0.04 \mathrm{U}_{\mu}^{-1}$ Taq polymerase. The cycling reaction was performed in a programmable thermal cycler (Takara PCR thermal cycler Dice, TP600 gradient, Takara Bio Inc.) at initial denaturation for $5 \mathrm{~min}$ at $95^{\circ} \mathrm{C}$, followed by 35 cycles of $95^{\circ} \mathrm{C}$ denaturation for $30 \mathrm{~s}, 60^{\circ} \mathrm{C}$ annealing for $30 \mathrm{~s}, 72^{\circ} \mathrm{C}$ extension for $1 \mathrm{~min}$ and a final extension for $7 \mathrm{~min}$ at $72^{\circ} \mathrm{C}$. PCR products were purified using the QIAquick PCR purification kit (Qiagen), followed by quality and quantity analysis using Nanodrop 1000 Spectrophotometer. Pure PCR products were sent for sequencing service using BigDye Terminator v3.1 Cycle Sequencing Kit (Applied Biosystems, Warrington, UK) and analyzed on the ABI 3100 Genetic Analyzer (Applied Biosystems). Sequence alignment and assembly was done by using DNA baser sequence assembly software (Heracle Biosoft SRL, Arges, Germany).

\section{RESULTS}

A total of $252 \beta$-TM patients from Sabah were recruited for this study. Frequency of $\beta$-thalassemia alleles in $\beta$-TM patients in Sabah population is shown in Table 1 , whereas the ethnic distribution among the $\beta$-TM patients is shown in Table 2. Filipino $\beta^{0}$-deletion was identified as the most common mutation with 460 alleles (91.3\%). A total of $219(86.9 \%)$ patients were homozygous for the Filipino $\beta^{0}$-deletion: $185(84.5 \%)$ were from the indigenous population; Kadazandusun (137), Rungus (20), Murut (10), Sungai (9), Bajau (4) and Bruneian (5). Two were found with mixed-indigenous ethnicity (indigenous-Sabah/Chinese (2)). The ethnicities for the remaining $32 \beta$-TM patients homozygous for Filipino $\beta^{0}$-deletion were not reported.

Compound heterozygosity of Filipino $\beta^{0}$-deletion was found in 22 $(8.7 \%)$ patients where 16 patients $(72.7 \%)$ had both Filipino 
$\beta^{0}$-deletion and $\beta^{+}$-mutations $\left(\beta^{\circ} / \beta^{+}\right)$. Among the 22 cases, 6 were found compound heterozygous with $\mathrm{CD} 26(\mathrm{G} \rightarrow \mathrm{A} ; \mathrm{Hb} \mathrm{E})$ and $\mathrm{CD} 19(\mathrm{~A} \rightarrow \mathrm{G}$; $\mathrm{Hb}$ Malay), respectively. Two were compound

Table 1 Frequency of $\boldsymbol{\beta}$-thalassemia alleles in $\boldsymbol{\beta}$-TM patients in Sabah population ( $n=252 ; 504$ alleles)

\begin{tabular}{|c|c|c|c|}
\hline $\begin{array}{l}\beta \text {-thalassemia } \\
\text { mutations }\end{array}$ & $\begin{array}{l}\text { Type of } \beta \text { - } \\
\text { thalassemia }\end{array}$ & $\begin{array}{l}\text { Number of } \\
\text { alleles (n) }\end{array}$ & $\begin{array}{c}\text { Frequency } \\
\text { (\%) }\end{array}$ \\
\hline Fil $\beta^{\circ}$-deletion & $\beta^{\circ}$ & 460 & 91.3 \\
\hline Codon $26(G \rightarrow A)(H b E)$ & $\beta^{+}$ & 8 & 1.6 \\
\hline Codon $19(A \rightarrow G)$ (Hb Malay) & $\beta^{+}$ & 7 & 1.4 \\
\hline Codon 41/42 (-TTCT) & $\beta^{\circ}$ & 6 & 1.1 \\
\hline Poly-A $(A \rightarrow G)$ & $\beta^{+}$ & 4 & 0.8 \\
\hline IVS II-654 $(\mathrm{C} \rightarrow \mathrm{T})$ & $\beta^{+}$ & 3 & 0.6 \\
\hline Codon 71/72 $(+A)$ & $\beta^{\circ}$ & 3 & 0.6 \\
\hline$-28(A \rightarrow G)$ & $\beta^{+}$ & 3 & 0.6 \\
\hline IVS I-5 $(G \rightarrow C)$ & $\beta^{+}$ & 2 & 0.4 \\
\hline Codon 8/9 ( + G) & $\beta^{\circ}$ & 2 & 0.4 \\
\hline Codon $17(\mathrm{~A} \rightarrow \mathrm{T})$ & $\beta^{\circ}$ & 1 & 0.2 \\
\hline Codon $30(\mathrm{G} \rightarrow \mathrm{C})$ (Hb Monroe) & $\beta^{\circ}$ & 1 & 0.2 \\
\hline IVS I-2 (T $\rightarrow G)$ & $\beta^{\circ}$ & 1 & 0.2 \\
\hline $\begin{array}{l}\text { Codons } 123 / 124 / 125 \\
\text { (-ACCCCACCC) }\end{array}$ & $\beta^{\circ}$ & 1 & 0.2 \\
\hline Unidentified & - & 2 & 0.4 \\
\hline Total & & 504 & 100 \\
\hline
\end{tabular}

Abbreviation: $\beta$-TM, $\beta$-thalassemia major. heterozygous with poly-A tail mutation (AATAAA $\rightarrow$ AATAGA) and $\mathrm{CD} 71 / 72(+\mathrm{A})$, respectively. The remaining four cases were compound heterozygous for CD $17(\mathrm{~A} \rightarrow \mathrm{T})$, IVS I-5 $(\mathrm{G} \rightarrow \mathrm{C})$, IVS II-654 $(\mathrm{C} \rightarrow \mathrm{T})$ and one rare mutation, Hb Monroe $(\mathrm{G} \rightarrow \mathrm{C})$. The second mutation for two cases could not be identified. Mutations common in West Malaysia were found in 11 (4.3\%) patients.

\section{DISCUSSION}

Sabah, a state in Malaysia, is situated at the northern part of the Borneo Island. In this report, we describe the spectrum of $\beta$-globin gene mutations identified in $252 \beta$-TM patients in Sabah. The mutations identified in this region showed great discrepancy when compared with the West Malaysia (Peninsular Malaysia)., ${ }^{5,6,14-20}$ These findings indicate a clear genetic difference between Sabah (East Malaysia) and West Malaysia. This can be attributed by regional differences in demography and that the population in Sabah and Peninsular Malaysia is genetically distinct historically.

The close proximity of Sabah in North Borneo and the Philippines has allowed migration drift to occur. The Filipino $\beta^{0}$-deletion was first reported by Motum et al. ${ }^{28}$ in a Filipino family and found in $45.8 \%$ of the $\beta$-globin mutant alleles in the Taiwan-Filipinos. ${ }^{28,29}$ This mutation was also found in Indonesians from the eastern part of Indonesia due to its adjacent geographical locations to Philippines. ${ }^{30,31}$ In our study, Filipino $\beta^{0}$-deletion was the predominant mutation identified in the indigenous population of Sabah (homozygosity: 219 (86.9\%) especially in Kadazandusun (137 $(62.6 \%))$. This is in keeping with previous studies, where the Fililpino

Table 2 Frequency of $\beta$-globin gene molecular defects and ethnicity distribution among $\beta$-TM patients in Sabah population ( $n=252$ )

\begin{tabular}{|c|c|c|c|c|c|c|c|c|c|c|c|}
\hline \multirow[b]{2}{*}{$\beta$-globin gene defect (n) } & \multirow[b]{2}{*}{ Genotype } & \multirow[b]{2}{*}{ Kadazandusun } & \multirow[b]{2}{*}{ Rungus } & \multirow[b]{2}{*}{ Murut } & \multirow[b]{2}{*}{ Sungai } & \multirow[b]{2}{*}{ Bajau } & \multirow[b]{2}{*}{ Bruneian ${ }^{\mathrm{a}}$} & \multirow[b]{2}{*}{ Chinese } & \multirow[b]{2}{*}{ Others } & \multicolumn{2}{|c|}{ Total } \\
\hline & & & & & & & & & & $\mathrm{N}$ & $\%$ \\
\hline Homozygous Fil $\beta^{\circ}$-deletion & $\beta^{\circ} / \beta^{\circ}$ & 137 & 20 & 10 & 9 & 4 & $5^{b}$ & $2^{c}$ & $32^{d}$ & 219 & 86.9 \\
\hline Heterozygous Fil $\beta^{\circ}$-deletion & & & & & & & & & & 22 & 8.7 \\
\hline Fil $\beta^{\circ}$-deletion/Hb E & $\beta^{\circ} / \beta^{+}$ & 1 & - & 1 & 2 & 2 & - & - & - & 6 & \\
\hline Fil $\beta^{\circ}$-deletion/Hb Malay & $\beta^{\circ} / \beta^{+}$ & 1 & - & - & 2 & 2 & 1 & - & - & 6 & \\
\hline Fil $\beta^{\circ}$-deletion/poly-A & $\beta^{\circ} / \beta^{+}$ & 1 & - & - & - & - & 1(Kedayan) & - & - & 2 & \\
\hline Fil $\beta^{\circ}$-deletion/codon 71/72 & $\beta^{\circ} / \beta^{\circ}$ & 1 & - & - & - & - & - & - & $1(\text { Sino- })^{e}$ & 2 & \\
\hline Fil $\beta^{\circ}$-deletion/codon 17 & $\beta^{\circ} / \beta^{\circ}$ & 1 & - & - & - & - & - & - & - & 1 & \\
\hline Fil $\beta^{\circ}$-deletion/IVS I-5 & $\beta^{\circ} / \beta^{+}$ & - & - & - & - & - & - & - & 1 (Jawa) & 1 & \\
\hline Fil $\beta^{\circ}$-deletion/IVS II-654 & $\beta^{\circ} / \beta^{+}$ & 1 & - & - & - & - & - & - & - & 1 & \\
\hline Fil $\beta^{\circ}$-deletion/Hb Monroe & $\beta^{\circ} / \beta^{\circ}$ & - & - & - & - & - & - & - & 1 (Jawa) & 1 & \\
\hline Fil $\beta^{\circ}$-deletion/unidentified & $\beta / \mathrm{UI}$ & - & 1 & - & 1 & - & - & - & - & 2 & \\
\hline Other $\beta$-thalassemia mutations & & & & & & & & & & 11 & 4.4 \\
\hline Homozygous codon $41 / 42$ & $\beta^{\circ} / \beta^{\circ}$ & - & - & - & - & - & - & 2 & - & 2 & \\
\hline Homozygous IVS II-654 & $\beta^{+} / \beta^{+}$ & - & - & - & - & - & - & 1 & - & 1 & \\
\hline Codon 8/9/poly-A tail & $\beta^{\circ} / \beta^{+}$ & - & - & - & - & - & 2 & - & - & 2 & \\
\hline$-28 /$ codon $41 / 42$ & $\beta^{+} / \beta^{\circ}$ & - & - & - & - & - & - & 2 & - & 2 & \\
\hline $\mathrm{Hb}$ E/IVS I-5 & $\beta^{+} / \beta^{+}$ & - & - & - & - & - & - & - & 1 (Malay) & 1 & \\
\hline $\mathrm{Hb}$ E/IVS I-II & $\beta / \beta^{\circ}$ & - & - & - & - & 1 & - & - & - & 1 & \\
\hline$-28 /$ codon $71 / 72$ & $\beta^{+} / \beta^{\circ}$ & - & - & - & - & - & - & 1 & - & 1 & \\
\hline \multirow[t]{2}{*}{ Cd 19/Cd 123/124/125 (-9bp) } & $\beta^{+} / \beta^{\circ}$ & - & - & - & - & - & - & - & 1 (Banjar) & 1 & \\
\hline & & 143 & 21 & 11 & 14 & 9 & 9 & 8 & 37 & 252 & 100 \\
\hline
\end{tabular}


$\beta^{0}$-deletion was also found in the Kadazandusun. ${ }^{21,22,32}$ We conclude that Filipino $\beta^{0}$-deletion is largely specific in its distribution, occurring predominantly in the indigenous population of Sabah.

In $\beta$-thalassemia, the majority of mutations are point mutations (such as single nucleotide substitutions), minor insertions or deletions within the gene or its immediate flanking sequence. ${ }^{7,8}$ The Fililpino $\beta^{0}$-deletion is the largest deletion seen among the mutations identified in Malaysia, which leads to a severe $\beta^{0}$-thalassemia phenotype with totally absence of $\beta$-globin chains expression. This deletion was first reported as $45 \mathrm{~kb}$ deletion ${ }^{17,23}$ and in a recent study, it was discovered as $118 \mathrm{~kb}$ deletion. ${ }^{33}$ The $5^{\prime}$ deletion breakpoint had been defined at the position -4279 relative to the mRNA capsite of the $\beta$-globin gene and the $3^{\prime}$ breakpoint extending to the downstream of $\beta$-globin gene, six olfactory reception genes (four functional OR genes and two OR pseudogenes) including one $\gamma$-globin enhancer located at OR52A1. This $\gamma$-globin enhancer contained enhancer element that conveys continuous expression of fetal globin genes. Deletion of this enhancer might contribute to a significant reduction of the compensatory $\gamma$-globin gene expression, leading to lower $\mathrm{Hb} \mathrm{F}$ production and exacerbate the phenotype of $\beta$-thalassemia. ${ }^{23,28,33}$

Common hemoglobin $(\mathrm{Hb})$ variants in West Malaysia were found to coexist with the Fililpino $\beta^{0}$-deletion. The $\mathrm{Hb}$ variants found in our study were $\mathrm{Hb}$ Malay and $\mathrm{Hb} \mathrm{E}$. $\mathrm{Hb} \mathrm{E}$ is a common $\beta^{+}-\mathrm{Hb}$ variant found among Malays. ${ }^{6}$ Coexistence of $\mathrm{Hb} \mathrm{E}$ with Filipino $\beta^{0}$-deletion had been reported in Thai population ${ }^{34}$ and three Indonesian patients. ${ }^{31}$ The Thai patient had severe hypochromic microcytic anemia and an elevation of $\mathrm{Hb} \mathrm{A}_{2}$ level. In our study six patients were found to coexist with $\mathrm{Hb} \mathrm{E}$, where only one was a Kadazandusun. The presence of $\mathrm{Hb}$ E mutation in Sabah may be due to intermarriage of Malays with the indigenous population.

Coexistence of Filipino $\beta^{0}$-deletion with some common mutations in West Malaysia was also found. Common $\beta$-thalassemia mutations were seen in seven $(2.8 \%)$ of $\beta$-TM patients, consisting of Poly-A $(\mathrm{A} \rightarrow \mathrm{G})$; CD 71/72 $(+\mathrm{A})$; CD $17(\mathrm{~A} \rightarrow \mathrm{T})$; IVS I-5 $(\mathrm{G} \rightarrow \mathrm{C})$ and IVS II-654 $(\mathrm{C} \rightarrow \mathrm{T})$. We may assume that the Filipino $\beta^{0}$-deletion allele was inherited from the parent who is from the indigenous population, whereas the second allele might be inherited from the parent who is Malaysian-Chinese or Malaysian-Malay from West Malaysia. However, further studies into ethnicity background in this group would be required.

In the transfusion dependent $\beta$-TM patients, 16 (72.7\%) were $\beta^{\circ}$ $\beta^{+}$. These patients may have been clinically severe as a consequence of gene modifiers. Environmental factors, intercurrent infections, nutritional status and access to health care facilities may be confounding factors. ${ }^{35}$

Eleven patients $(4.4 \%)$ were found without the Filipino $\beta^{0}$-deletion allele and no Kadazandusun were found in this group. The majority were Chinese, followed by Malay, Bruneian, Bajau and Banjar. Among the six Chinese patients, the mutations inherited were in concordance with the common mutations found among Malaysian-Chinese in West Malaysia. ${ }^{5,6,14-20}$ Similar observation was noticed in the Malay patient with $\mathrm{Hb}$ E/IVS I-5, which are common mutations among Malaysian-Malays in West Malaysia., ${ }^{5,6,14-20}$ The remaining four patients inherited some rare mutations (Hb Monroe, CD 123/124/ 125 , IVS I-2 $(\mathrm{T} \rightarrow \mathrm{G})$ and CD 8/9 $(+\mathrm{G}))$, which were rarely found in West Malaysia.

The patient who was compound heterozygous for Filipino $\beta^{0}$ deletion with $\mathrm{Hb}$ Monroe originated from Jawa. This rare mutation was first reported in 1988 by Gonzalez-Redondo et al. in a transfusion-dependent 15-year-old black female from USA and is commonly found in Black, Libyan, Tunisian, Mediterranean and
African-Americans. ${ }^{36-38} \mathrm{Hb}$ Monroe (NM_000518.4:c.92G >C) also known as $\mathrm{Hb}$ Kairouan and has a $\beta^{0}$-thalassemia phenotype. The mutation is located at codon 30 of exon 1 with position at chromosome 11, 5248 160. In the normal $\beta$-globin gene, codon 30 (AGG) is divided by intron 1 and AG dinucleotide is required for normal splicing. The change of nucleotide $\mathrm{G}$ to $\mathrm{C}$ at position -1 of intron 1 results in transition of Arg to $\mathrm{Thr}$ (AGG $\rightarrow$ ACG), forming the mutant hemoglobin ( $\mathrm{Hb}$ Monroe), which severely reduces the utilization of the normal $5^{\prime}$ splice site. The splicing efficiency will be reduced as $98 \%$ of the correct splicing is inhibited and no normal mRNA is formed (Itha ID: 100; Hb Var ID: 290). ${ }^{37-40}$

Compound heterozygous of CD 123/124/125 with CD 19 was found in an indigenous patient with Banjar ethnicity. This mutation was first reported in 1991 by Fucharoen et al. ${ }^{41}$ in a 3 -year-old Northeastern Thai patient with large inclusion bodies observed in peripheral blood. This variant is a $\beta^{0}$-thalassemia with deletion of eight bases ( $5^{\prime}$-ACCCCACC- $3^{\prime}$ ) in CD 123/124/125, exon 3 of $\beta$ globin gene situated at chromosome 11, from 5246894-5246902 (NM_000518.4:c.370_378delACCCCACCA). This mutation is also known as beta-Khon Kaen and results in formation of big inclusion bodies due to the changes of the reading frame of 135 amino acids with the new codon 136, which is a stop codon (TAA). The normal amino-acid residues of the $\beta$-globin chain are eliminated from codon 123-146, where the H-helix involved in $\alpha_{1} \beta_{1}$ contact and $\alpha_{1} \beta_{2}$ subunit interactions will be interfered. The mutant globin chain does not interact with the $\alpha$-globin chain and will be removed by proteolysis. Hence, the chains produced are highly unstable and are likely to be degraded soon after translation (Itha ID: 246; Hb Var ID: 953). ${ }^{39,40}$

Compound heterozygous of $\mathrm{Hb} \quad \mathrm{E}$ with IVS $\mathrm{I}-2 \quad(\mathrm{~T} \rightarrow \mathrm{G}$; AGGTTGGT $\rightarrow$ AGGGTGGT) $\quad$ (NM_000518.4:c.92 + 2T > G) was found in an indigenous patient with Bajau ethnicity. IVS I-2 is commonly found in Tunisians. This rare mutation results in $\beta^{0}$ thalassemia with the transition of $\mathrm{T}$ to $\mathrm{G}$ at intron 1 with position at chromosome 11, 5248158. The transition changes in the GT dinucleotide disturbs the normal splicing event and no normal mRNA is produced (Itha ID: 104; Hb Var ID: 821$).{ }^{39,40}$

In our study, compound heterozygous CD 8/9 $(+\mathrm{G})$ with poly-A $(A \rightarrow G)$ were seen in two Bruneian patients. This mutation is commonly found in Asian Indians, such as Pathans with the frequency of $48.3 \%,{ }^{42}$ followed by Pakistani (25.9\%), Punjabi $\left(31.9 \%{ }^{42}\right)$, Iranian $(11.03 \%)$, Bangladeshi $(10 \%)$ and Spanish $\left(8.6 \%{ }^{43}\right)$. CD 8/9 (+G) (NM_000518.4:c.27_28insG) results by insertion of a $\mathrm{G}$ nucleotide between the codons 8 and 9 of $\beta$-gene, located at exon 1 of chromosome 11, at 5248224-5248225. It changes the sequences AAG TGT (Lys; Ser) to AAG G TCT. This frameshift results in the termination of translation at codon 22 (TGA) and has a $\beta^{0}$-thalassemia phenotype with complete absence of $\beta$ globin chain production (Itha ID: 62; Hb Var ID: 786). ${ }^{39,40,42-44}$

\section{CONCLUSION}

Genotype characterization in thalassemia is crucial to the successful implementation of prenatal diagnosis and disease management strategies. Ethnicity is an important factor in the molecular diagnosis of $\beta$-thalassemia. In this study, the spectrum of $\beta$-thalassemia mutations in Sabah was delineated. This report reveals a notable regional specificity of the Filipino $\beta^{0}$-deletion. Given the demonstrated low frequency of $\beta$-thalassemia alleles in the indigenous population of Sabah, the present study is informative. This finding suggests that the indigenous population of Sabah and Philippines may belong to the same stock and origin. Importantly testing for the 
Filipino $\beta^{0}$-deletion as the first step identified this mutation in $86.9 \%$ of $\beta$-TM patients in Sabah. Thus, a cost-effective strategy would be to do Gap-PCR for the Filipino $\beta^{0}$-deletion as the first step to identify mutations in $\beta$-TM patients.

\section{CONFLICT OF INTEREST}

The authors declare no conflict of interest.

\section{ACKNOWLEDGEMENTS}

We thank the Director General of Health, Malaysia for permission to publish this paper (NMRR-10-850-7075). This study was supported by E-Science Research Grant, Ministry of Science, Technology and Innovation (MOSTI) 02-01-04-SF1031 awarded to George Elizabeth.

1 Population distribution and basic demographic characteristic reportDepartment of Statistics Malaysia [homepage on the internet]. c2010 [updated 2013 Sept 11; cited 2013 Sept 12]. Available from http://www.statistics.gov.my/portal/index.php?option=com_content\&id=1215\&ltemid=89\&lang=en (2010).

2 ICID_-Irrigation \& Drainage in the World-A Global Review. pp 1-6 [homepage on the Internet]. c2010 [updated 2013 Sept 11; cited 2013 Sept 12]. Available from http://www.icid.org/i_d_malaysia.pdf.

3 Total population by ethnic group, administrative district and state, MalaysiaDepartment of Statistics Malaysia [homepage on the Internet]. c2010 [updated 2013 Sept 11; cited 2013 Sept 12]. Available from http://www.statistics.gov.my/portal/download_Population/files/population/05Jadual_Mukim_negeri/Mukim_Sabah.pdf (2010).

4 Borneo Hidden Treasures website [homepage on the Internet]. c2013 [updated 2010 May; cited 2013 Sept 12]. Available from http://goeasytravel.co/get/?page_id=741.

5 Tan, J. A. M. A., George, E., Tan, K. L., Chow, T., Tan, P. C., Hassan, J. et al. Molecular defects in the $\beta$-globin gene identified in different ethnic groups/populations during prenatal diagnosis for $\beta$-thalassaemia: a Malaysian experience. Clin. Exp. Med. 4, 142-147 (2004).

6 George, E., Li, H. J., Fei, Y. J, Reese, A. L., Baysal, E., Cepreganova, B. et al. Types of thalassameia among patients attending a large university clinic in Kuala Lumpur, Malaysia. Hemoglobin 16, 51-66 (1992).

7 Thein, S. L. Genetic insights into the clinical diversity of $\beta$ thalassaemia. Br. J. Haematol. 124, 264-274 (2004).

8 Thein, S. L. Pathophysiology of $\beta$ thalassemia-a guide to molecular therapies. Hematology Am. Soc. Hematol. Edu. Program 1, 31-37 (2005).

9 Bowden, D. K. Abnormal laboratory results: screening for thalassaemia. Aust. Prescr. 24, 120-123 (2001)

10 Ho, P., Hall, G., Luo, L., Weatherall, D. \& Thein, S. Beta-thalassaemia intermedia: is it possible consistently to predict phenotype from genotype? Br. J. Haematol. 100, 70-78 (1998)

11 George, E. Beta thalassaemia major in Malaysia, an on-going public health problem. Med. J. Malaysia 56, 397-400 (2001).

12 Quek, L. \& Thein, S. L. Molecular therapies in $\beta$-thalassaemia. Br. J. Haematol. 136, 353-365 (2006).

13 Fucharoen, S. \& Winichagoon, P. Prevention and control of thalassemia in Asia. Asian Biomed. 1, 1-6 (2010).

14 Sivalingam, M., Looi, M., Zakaria, S., Hussin, N., Alias, H., Latiff, Z. et al. Molecular study and genotype/phenotype correlation of $\beta$ thalassemia in Malaysia. Int. J. Lab. Hematol. 34, 1-6 (2012).

15 George, E., George, R., Ariffin, W. A., Mokhtar, A. B., Azman, Z. A. \& Sivagengei, K. Spectrum of beta-thalassaemia mutations in transfusion dependent thalassaemia patients: practical implications in prenatal diagnosis. Med. J. Malaysia 48 325-329 (1993).

16 George-Kodiseri, E., Yang, K. G., Kutlar, F., Wilson, J. B., Kutlar, A., Stoming, T. A. et al. Chinese in west Malaysia: the geography of beta thalassaemia mutations. Singapore Med. J. 31, 374-377 (1990).

17 Yang, K. G., Kutlar, F., George, E., Wilson, J. B., Kutlar, A., Stoming, T. A. et al. Molecular characterization of $\beta$-globin gene mutations in Malay patients with $\mathrm{Hb}$ E- $\beta$-thalassaemia and thalassaemia major. Br. J. Haematol. 72, 73-80 (1989).

18 George, E., Huisman, T. H., Yang, K. G., Kutlar, F., Wilson, J. B., Kutlar, A. et al. First observation of haemoglobin Malay alpha 2B2 26 (B1) Asn-Ser-a case report. Med. J. Malaysia 44, 259-262 (1989).
19 George, E. The clinical severity of beta-thalassemia mutations in west Malaysia. Southeast Asian J. Trop. Med. Public Health 26, 225 (1995).

20 Tan, J. A. M. A., Chin, P. S., Wong, Y. C., Tan, K. L., Chan, L. L. \& George, E. Characterisation and confirmation of rare beta-thalassaemia mutations in the Malay, Chinese and Indian ethnic groups in Malaysia. Pathology 38, 437-441 (2006).

21 Thong, M. K. \& Soo, T. The spectrum of beta-globin gene mutations in children with beta-thalassaemia major from Kota Kinabalu, Sabah, Malaysia. Singapore Med. J. 46 340-343 (2005).

22 Thong, M. K., Rudzki, Z., Hall, J., Tan, J. A., Chan, L. L. \& Yap, S. F. A single, large deletion accounts for all the beta-globin gene mutations in twenty families from Sabah (north Borneo), Malaysia. Hum. Mutat. 13, 413 (1999).

23 Waye, J. S., Eng, B., Hunt, J. A. \& Chui, D. H. K. Filipino $\beta$-thalassemia due to a large deletion: identification of the deletion end points and polymerase chain reaction (PCR)based diagnosis. Hum. Genet. 94, 530-532 (1994).

24 Old, J. M. Detection of mutations by the amplification mutation system. Prot. Human Mol. Genet. Methods Mol. Bio. 9, 77-84 (1991).

25 Old, J. M. Screening and genetic diagnosis of haemoglobin disorders. Blood Rev. 17, 43-53 (2003)

26 Clark, B. \& Thein, S. Molecular diagnosis of haemoglobin disorders. Clin. Lab. Haematol. 26, 159-176 (2004).

27 Knott, M., Ramadan, K., Savage, G., Jones, F., El-Agnaf, M., McMullin, M. et al. Novel and mediterranean $\beta$ thalassemia mutations in the indigenous northern Ireland population. Blood Cells Mol. Dis. 36, 265-268 (2006).

28 Motum, P, Kearney, A, Hamilton, T \& Trent, R. Filipino beta zero thalassaemia: a high $\mathrm{Hb} \mathrm{A}$ beta zero thalassaemia resulting from a large deletion of the 5'beta globin gene region. J. Med. Genet. 30, 240-244 (1993).

29 Ko, T. M., Caviles, A. Jr, Hwa, H. L., Liu, C. W., Hsu, P. M. \& Chung, Y. P. Prevalence and molecular characterization of $\beta$-thalassemia in filipinos. Ann. Hematol. 77, 257-260 (1998).

30 Setianingsih, I., Williamson, R., Marzuk, S., Harahap, A., Tamam, M. \& Forrest, S. Molecular basis of $\beta$-thalassemia in Indonesia: application to prenatal diagnosis. Mol. Diagn. 3, 11-20 (1998).

31 Setianingsih, I., Williamson, R., Daud, D., Harahap, A., Marzuki, S. \& Forrest, S. Phenotypic variability of filipino $\beta^{\circ}$-thalassemia/HbE patients in Indonesia. Am. J. Hematol. 62, 7-12 (1999).

32 Tan, J. A. M. A., Lee, P. C., Wee, Y. C., Tan, K. L., Mahali, N. F., George, E. et al. High prevalence of alpha-and beta-thalassemia in the kadazandusuns in east Malaysia: challenges in providing effective health care for an indigenous group. J. Biomed. Biotechnol. 706872, 1-5 (2010).

33 Van Ziffle, J., Yang, W. \& Chehab, F. F. Homozygous deletion of six olfactory receptor genes in a subset of individuals with beta-thalassemia. PLoS One 6, e17327 (2011).

34 Yamsri, S., Sanchaisuriya, K., Fucharoen, G. \& Fucharoen, S. Genetic origin and interaction of the filipino $\beta^{0}$-thalassemia with $\mathrm{Hb} E$ and $\alpha$-thalassemia in a Thai family. Transl. Res. 159, 473-476 (2012).

35 George, E. HbE $\beta$-thalassaemia in Malaysia: revisited. J. Hematol. Thromb. Dis. 1, 2 (2013).

36 Gonzalez-Redondo, J., Stoming, T., Lanclos, K., Gu, Y., Kutlar, A., Kutlar, F. et al. Clinical and genetic heterogeneity in black patients with homozygous beta-thalassemia from the southeastern united states. Blood 72, 1007-1014 (1988).

37 Moosa, M. M., Ayub, M. I., Bashar, A. M. A. E., Sarwardi, G., Khan, W., Khan, H. et al. Combination of two rare mutations causes $\beta$-thalassaemia in a bangladeshi patient. Genet. Mol. Biol. 34, 406-409 (2011).

38 Vidaud, M., Gattoni, R., Stevenin, J., Vidaud, D., Amselem, S., Chibani, J. et al. A 5'splice-region $\mathrm{G} \rightarrow \mathrm{C}$ mutation in exon 1 of the human beta-globin gene inhibits premRNA splicing: A mechanism for $\beta^{+}$-thalassemia. Proc. Natl Acad. Sci. 86, 1041-1045 (1989).

39 Haemoglobin Variants Database of human haemoglobin Variants and thalassaemia mutations [homepage on the internet]. c2013 [updated 2013 Sept; cited 2013 Sept 12]. Available from http://globin.bx.psu.edu/hbvar.

40 Ithanet Database of Ithnanet Portal [homepage on the internet]. c2013 [updated 2013 Sept; cited 2013 Sept 12]. Available from http://www.ithanet.eu/db/ithagenes.

41 Fucharoen, G., Fuchareon, S., Jetsrisuparb, A. \& Fukumaki, Y. Eight-base deletion in exon 3 of the beta-globin gene produced a novel variant (beta khon kaen) with an inclusion body beta-thalassemia trait. Blood 78, 537-539 (1991).

42 Khattak, S. A. K., Ahmed, S., Anwar, J., Ali, N. \& Shaikh, K. H. Prevalence of various mutations in beta thalassaemia and its association with haematological parameters. J. Pak. Med. Assoc. 62, 40-43 (2012).

43 Villegas, A., Ropero, P., Gonzalez, F. A., Martí, E., Anguita, E. \& De Blas, J. High incidence of the $\operatorname{CD} 8 / 9(+\mathrm{G})$ beta $^{0}$-thalassemia mutation in Spain. Haematologica $\mathbf{8 3}$, 1066-1068 (1998).

44 George, E., Teh, L. K., Lai, M. I. \& Tan, J. A. M. A. Beta thalassaemia mutations in Malays: a simplified cost-effective strategy to identify the mutations. MJMHS 8, 45-53 (2012). 